\title{
The Cultures Of International Management
}

\author{
Carlos B. Gonzalez, California State Polytechnic University, Pomona
}

\begin{abstract}
In this paper I present an approach based on Cultural Studies to conceive of and pursue cultural inquiry in international management. For this purpose, I first develop a genealogical framework for understanding how the international management literature has engaged with culture over the past forty years. This framework focuses on decisions that international management scholars have made as they attempt to address culture in their research. It also focuses on the consequences of these decisions, which have skewed the field towards certain intellectual positions and have maintained culture as a problematic concept. In the last section I present an alternative approach situated within Cultural Studies to address the problem of culture in international management scholarship.
\end{abstract}

Keywords: culture, research, international management

\section{INTRODUCTION}

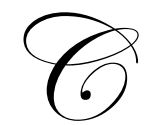

ulture is a key concept in international management scholarship both for research that focuses on managing cultural differences among individuals in organizations as well as research that makes comparisons across organizations in different geographic settings (Adler, 1984). It is assumed that culture is central for organizational processes, as it influences managerial performance and how organizations adapt to their environment (e.g. Roberts \& Boyacigiller, 1984; Erez \& Earley, 1993; Sekaran, 1983). Given the presumed influence culture exerts on organizational processes, both the at micro level of human behavior and at the macro level of organizational adaptation, international management scholars have put great effort into developing a science of culture.

Yet, scholars within the field have confronted several difficulties when addressing culture in their research, encountering many obstacles to ultimately developing a uniform understanding of the concept (e.g. Bhagat \& McQuaid, 1982; Cavusgil \& Das, 1997; Drenth, 1985; Hofstede, 2006; Lim \& Firkola, 2000; Gelfand, Erez, \& Aycan, 2007; Roberts, 1970; Roberts \& Boyacigiller, 1984; Tsui, Nifadkar \& Yi Ou, 2007; Werner, 2002). Beginning with the work of Haire, Ghiselli \& Porter (1966) as the first scholars to clearly focus on culture, the field of international management has gone through over forty years of continuing debate regarding the usefulness of culture for the purposes of research (e.g. Triandis, 2003). This ongoing debate can be described as the problem of culture, which has emerged as researchers attempt to develop a general theory of culture, along with corresponding methodologies that can predict culture's effect on different organizational variables (e.g. Aycan, 2000; Roberts, 1970; Roberts \& Boyacigiller, 1984; Smith, 2003).

Even though the problem of culture has not been solved, in recent years there has been an explosion of cultural inquiry within international management. The emergence of Geert Hofstede's work, in particular Culture's Consequences (1980), was a turning point for the field, with hundreds of studies adopting Hofstede's framework. Despite difficulties, it seemed as if the field had achieved the sought-after general theory of culture and had agreed on adequate cultural methodologies. This trend appears to sustain claims that Hofstede's work has become a paradigm for international management research (Søndergaard, 1994).

In addition to Hofstede's accomplishments, the amount of work dedicated to international business research has accelerated at an astonishing rate compared to the early days of the field during the 1960s. This surge of research has produced new calls for greater theoretical and methodological sophistication, more collaborative work, and more 
integrative frameworks (Boyacigiller \& Adler, 1991; Kitayama, 2002; Meyer, 2007; Tsui, 2004; Tsui et al., 2007; Wright \& Ricks, 1994). Due to this rise in new research, it is not surprising that debates about the usefulness of cultural considerations for international management have also increased (e.g. Singh, 2007). Further, the number of recent articles and books calling for greater sophistication in statistical methods based on precise constructs of culture seems to signify that a new "wave" of debates concerning theoretical and methodological issues is upon us (e.g. Cavusgil \& Das, 1997; Earley \& Singh, 2000; Fisher et al., 2005; Johnson, Lenartowicz \& Apud, 2006; Kitayama, 2002; Gelfand, Erez \& Aycan, 2007; Kirkman, Lowe \& Gibson, 2006; Hofstede, 2006; Lenartowicz \& Roth, 1999; Leung et al., 2005; Lim \& Firkola, 2000; Meyer, 2007; Miller, 2002; Shaffer \& Riordan; 2003; Shenkar, 2001; Tjosvold \& Leung, 2003; Tsui, 2004; Tsui, Nifadkar \& Yi Ou, 2007; Werner, 2002).

This paper is located within this new "wave" of discussions, but my goal is not to expand on or refine current constructs and notions of culture in the international management literature. Rather, informed by the "field" of Cultural Studies and postmodern organizational theory, my aim is to present newer approaches for conceiving of and pursuing cultural inquiry. Accordingly, this paper serves one main objective: to introduce Cultural Studies theorizing in international management scholarship. Through this objective, the paper engages with the problem of culture in a way that responds to exhortations by international management scholars calling for the integration of contextualized approaches to culture (e.g. Tsui, 2004; Tsui et al., 2007; Gelfand et al., 2007), for the incorporation of contemporary cultural inquiry that the field is not yet acknowledging (e.g. Weisinger \& Salipante, 2000), as well as the application of dynamic and malleable notions of culture (e.g. Erez \& Gati; 2004, Leung et al., 2005).

In order to situate my arguments within the contemporary and interdisciplinary space of Cultural Studies, I develop a framework for understanding how international management scholarship has engaged with culture over the years. This framework allows me to describe certain decisions international management scholars have made when attempting to solve the problem of culture and the consequences of these decisions in skewing the field into specific intellectual positions. Understanding the field in this manner opens a door toward the repositioning of culture that I advocate in this paper.

To be clear, this is not a comprehensive literature review. Over the years many in-depth reviews have already been published (e.g. Aycan, 2000; Barret \& Bass, 1976; Bhagat \& McQuaid, 1982; Boyacigiller et al., 1996; Cavusgil \& Das, 1997; Gelfand, Erez, \& Aycan, 2007; Lenartowicz \& Roth, 1999; Leung et al., 2005; Roberts, 1970; Tsui, Nifadkar \& Yi Ou, 2007, Werner, 2002). Rather, by historicizing the practices of cultural inquiry and the pragmatic decisions made by scholars within international management when addressing culture as a problem, this paper is closer to a genealogical understanding (Foucault, 1972).

For this purpose, I recognize three different phases in the articulation of the notion of culture within the field: The quest for methods, the attainment, and the post-attainment phases. My analysis focuses on the on-going debates in the field regarding the epistemological status of "culture." In general, my representation of these debates constitute "the cultures of international management," a re-presentation made possible, as will eventually become clear, by my location at the onset in a Cultural Studies perspective.

The paper unfolds as follows: In the first section I discuss the quest for methods phase, characterized by the work of international management scholars who attempted to develop a scientific understanding of international management. In the second section I present the attainment phase, characterized by the work of scholars who decided to conduct research based on specific methodological approaches and constructs of culture in order to understand how to manage across cultures. Lastly, I consider the possibility of a post-attainment phase in international management scholarship by discussing the notion of culture I advocate in this paper and the contributions that Cultural Studies can make to the field via an ontological repositioning of the idea of culture. Table 1 summarizes these arguments. 
Table 1

The Cultures of International Management

\begin{tabular}{|c|c|c|c|}
\hline $\begin{array}{l}\text { Phases in the } \\
\text { Articulation of } \\
\text { "Culture" }\end{array}$ & Periods within each phase & Dominant characteristics & Representative works \\
\hline \multirow[t]{3}{*}{ Quest for methods } & - Comparative management & - $\quad$ Organizational Comparisons & $\begin{array}{l}\text { Haire, Ghiselli \& Porter, } \\
1966\end{array}$ \\
\hline & - $\quad$ Value orientation & $\begin{array}{ll} & \text { Preference for specific } \\
\text { solutions }\end{array}$ & $\begin{array}{l}\text { Parsons, } 1964 \\
\text { Kluckhohn 1951, } 1962 \\
\text { Kluckhohn \& Strodbeck, } \\
1961 \\
\text { Kroeber \& Kluckhohn, } 1952 \\
\end{array}$ \\
\hline & - Culture as a parameter & $\begin{array}{ll}\text { - } & \text { Systematically organized } \\
\text { - } & \text { Deduct culture }\end{array}$ & Roberts, 1970 \\
\hline \multirow[t]{4}{*}{$\underline{\text { Attainment }}$} & $\begin{array}{ll}\text { - } & \begin{array}{l}\text { Cross-cultural } \\
\text { management }\end{array} \\
\end{array}$ & - $\quad$ Cultural differences & Adler, 1984 \\
\hline & - $\quad$ Epistemological concerns & - General theory of culture & $\begin{array}{l}\text { Roberts \& Boyacigiller, } \\
1984\end{array}$ \\
\hline & - The "rush forward" & - $\quad$ Parameter & $\begin{array}{l}\text { Hofstede, } 1980 \\
\text { House et al. } 2004\end{array}$ \\
\hline & $\begin{array}{l}\text { - } \\
\text { culture debates }\end{array}$ & - "Validity" of culture & $\begin{array}{l}\text { Redding, } 1994 \\
\text { Boyacigiller \& Adler } 1994 \\
\text { Cavusgil \& Das, } 1997 \\
\text { Weisinger \& Salipante, } 2000 \\
\text { Tsui et al, } 2007 \\
\end{array}$ \\
\hline$\underline{\text { Post-Attainment? }}$ & $\begin{array}{l}\text { Postmodern, } \\
\text { poststructuralist, \& } \\
\text { postcolonial org. theory } \\
\text { (not discussed in this } \\
\text { paper) } \\
\text { - Cultural Studies }\end{array}$ & $\begin{array}{l}\text { - } \quad \text { Changes in culture - idea, } \\
\text { practice, and as social reality } \\
\text { - } \quad \text { Practices of cultural knowledge } \\
\text { - } \quad \text { Cultural knowledge and power }\end{array}$ & $\begin{array}{l}\text { Williams 1958, 1961, 1976, } \\
1982 \\
\text { Kroeber \& Kluckhohn, } 1952 \\
\text { Rosaldo, 1993,1997 } \\
\text { Hall, 1980a, 1980b, } 1996 \\
\text { 1997a, 1997b }\end{array}$ \\
\hline
\end{tabular}

\section{THE QUEST FOR METHODS PHASE}

In general, the quest for methods phase was a period in which scholars interested in international management issues established the foundations of a scholarly field based on sound scientific methods for comparative research while also attempting to develop theoretical understandings for culture as such. That is, international management research considered issues of culture, if at all, primarily as a methodological issue with some epistemological concerns appearing more clearly at the end of this phase. The phase ended with recognition that despite its methodological soundness the field lacked conceptual sophistication in its understanding of culture.

I distinguish two periods in this phase. The first period is exemplified by the work of pioneers like Harbison \& Myers (1959), Farmer \& Richman (1965), and Haire, Ghiselli \& Porter (1966). These scholars developed a set of approaches for comparative studies of management in different geographic settings. The second period comprises the work of scholars who expanded on the work done in the first period by developing cultural variables, despite the absence of a clear theory or definition of culture specific to international management (e.g. Lammers \& Hickson, 1979). These two periods are bridged by the apparently unreflective adoption of the notion of "value orientation" borrowed from certain works in structural functionalist cultural anthropology. The borrowing of this notion will prove to have everlasting consequences for the field. 


\section{Comparative Management: The Beginnings}

The foundational role of Harbison \& Myers (1959), Farmer \& Richman (1965), and Haire, Ghiselli, \& Porter (1966) still echoes in many works within the field, and it is for this reason that I initiate the discussion by acknowledging their legacy as an often forgotten point of origin for the problem of culture. The work of this group of scholars had a common interest: to contribute to the economic development of nations and to introduce the science of management into developing countries. Their contribution can be summarized as follows:

1. They started a tradition in comparative management, where the unstated norm for comparison was the industrialized nations, in particular the US.

2. Initiated a discourse within the nascent field of international management aimed at using the scientific method as exemplified by positivist research to discover managerial universals that could be transplanted around the globe.

Of particular importance for this phase is Haire, Ghiselli and Porter's work. They demonstrated how surveybased research could be integrated into international management by providing examples of questionnaires, discussing how to deal with issues of translation, specifying the need to define culture as an independent variable, and addressing issues of sampling. All these contributions forward to standards of comparison, which promised to contribute to the generalizability and validity of findings in international management scholarship. Haire, Ghiselli and Porter's work is perhaps the most influential approach for international management research to these days.

\section{Bridging The Periods: Value Orientation And The Study Of Culture}

Farmer \& Richman (1965) and Haire, Ghiselli, \& Porter (1966) clearly suggested the need for a notion of culture in order to explain the process of management adaptability to different settings. However, if culture was the principle that could explain managerial adaptability then there was a need for a precise unifying construct that would allow for addressing the variability in these settings. But even if a precise construct of culture was obtained, how could it be made operational? International management scholars addressed these questions by incorporating insights from the work of cultural anthropologists Kluckhohn (1951, 1962), Kroeber \& Kluckhohn (1952), Kroeber \& Parsons (1958) and Kluckhohn \& Strodbeck (1961).

As Schein (1985) explains, cultural research in organizational studies based on the principle of value orientation such as Hall (1959) or Hofstede (1980) can be traced back to the work of Kluckhohn \& Strodbeck (1961). A connection between the fields of international management and cultural anthropology was made at this historical juncture. However, this connection was possible because of the already dominant conceptual influence of structural functionalism in both fields of knowledge at the time. That is, the work of Kluckhohn $(1951,1962)$, Kroeber \& Kluckhohn (1952), Kroeber \& Parsons (1958), Kluckhohn \& Strodbeck (1961), Farmer \& Richman (1965) and Haire, Ghiselli, \& Porter (1966) all share the influence of structural functionalism from the work of Talcott Parsons, which permeated US social thought and research during the 1940s, 1950s, and 1960s. Parsons' (1964) focus on cultural values as constitutive of the core stabilizing mechanism of the social system, offered the connecting principle for both fields.

While citing the relevance of Parsonian thought for the development of organizational science is not a new argument (e.g. Burrell, 1996; Burrell \& Morgan, 1979; Marsden \& Townley, 1996; Weiss, 1983), I do want to call particular attention to the impact of structural functionalism as a historical fact for the study of culture in international management.

\section{The Route To Culture: Culture As A Parameter}

In the late 1960s and the 1970s, the work of structural functionalist cultural anthropologists along with the work of Farmer \& Richman and Haire, Ghiselli \& Porter established the foundations for research on culture in international management. The turn to culture in international management research was developing momentum. 
However, there was no clear and operationalizable construct of culture in these works. It is for this reason that Roberts (1970) makes the following and now famous remark about the need for a construct of culture:

Without some theoretical notions explaining culture and predicting its effect on other variables, we cannot make sense of cross-cultural comparisons (1970: 330).

As this quote illustrates, scholars working within this period of the quest for methods phase were starting to shift their focus from ambiguous cultural variables towards the development of a cultural theory that unambiguously explained the process of managerial adaptation.

\section{THE ATTAINMENT PHASE}

The attainment phase characterizes the current state of affairs for cultural research in international management. Scholars within this phase have adopted specific constructs of culture (e.g. Hofstede, 1980) and have produced an astonishing high number of culture based research. However, many other scholars are voicing their alarm about the field's status quo (e.g. Redding, 1994; 2003).

To develop on this, I describe three periods within the attainment phase. The first period is characterized by the work of scholars, who following the arguments in the last period of the quest for methods phase, called for the development of a general theory for the study of culture. The second period comprises the work of scholars who decided to adapt the work of Hofstede and others and proceeded to conduct cultural research as if the field had achieved a generally agreed upon parameter of culture. Lastly, there is the work of scholars that are cautioning about the "boom" of research in international management that decided to ignore epistemological and methodological problems with dominant constructs of culture in international management.

\section{Cross-Cultural Management: The Search For A Construct Of Culture}

The first period of the attainment phase was characterized by the work of scholars interested in "distilling" the concept of culture. Scholars in this period attempted to develop a rigorous science of culture for the management of people and organizations across cultures (e.g. Adler, 1984; Adler, 1983a, 1983b, 1983c; Aldemir, 1986; Child \& Tayeb, 1982; Drenth, 1985; Evan, 1973; Feldman, 1986; Inzerilli, 1981; Jamieson, 1982; Lincoln, Hanada \& Olsen, 1981; Roberts \& Boyacigiller, 1984; Sekaran, 1983; Sorge; 1982; Triandis, 1982). In short, scholars wanted to develop a general theory of culture and prescribe generally agreed upon methods. It is for this reason that Roberts \& Boyacigiller (1984) affirm that:

A good paradigm will either specify a definition of culture or replace it with a set of measurable variables that might together reflect potential important setting impacts on organizations (Roberts \& Boyacigiller, 1984: 428).

\section{Epistemological Concerns}

As the previous quote illustrates, the first period of the attainment phase was ending and a new period was emerging. Scholars in the early stages of this period continued their call for a paradigm that could provide a general theory of culture and describe adequate cultural methodologies (e.g. Adler, 1983b; Adler 1983c; Adler \& Villafranca, 1981; Roberts \& Boyacigiller, 1984; Sekaran, 1983)

However, despite the interest at this point to engage with epistemological problems for the acquisition of cultural knowledge and attempts to develop a comprehensive theory for the study of culture in international management, eventually these efforts seem to have waned. Many international management scholars decided to take a different approach, going ahead and conducting research based on several constructs of culture already available while giving less importance to the lack of a general theory of culture to inform their research. The sheer number of scholars that opted for this other "path" had the effect of declaring an implicit moratorium on the epistemological and methodological arguments for the study of culture as if the question of "culture" in the field had been settled. 


\section{International Management: The Rush Forward}

This issue is exemplified by the typologies of culture and cultural methodologies of Hall \& Hall (1990), Hofstede (1980), House et. al (2004), Triandis (1983), Trompenars (1993), and Schwartz (1992, 1994). Scholars within this group have focused on doing cultural research using culture as an independent variable. This decision has produced a great increase in cultural research using one of the aforementioned theories of culture, in particular Hofstede's (1980).

This rush to research could be attributed to the impatience among international management scholars who, after more than 40 years of debate about culture, decided to take a stand on the issue and show what the field could do with the knowledge it had already acquired (e.g. Lim \& Firkola, 2000).

\section{The Problem Of Culture: The Re-Emergence Of The Culture Debates}

Even though it is clear now that mainstream international management has adopted the typologies of cultures developed by Hofstede and others (e.g. Daft \& Lewin, 1990); the field has never achieved a consensus about culture. It is for this reason that some scholars working from within the attainment phase are calling for the critical assessment of contemporary cultural inquiry in international management. The calls for change can further be organized into three groups. First, there is the increasing number of scholars that question the unreflective adoption of Hofstede's research (e.g. Hofstede, 1991; Kirkman et al., 2006; McSweeney, 2002). Second, is the work of scholars, who within a positivist epistemology and functionalist paradigm, have challenged the adequacy of current constructs and methodologies for cultural inquiry in international management (e.g. Cavusgil \& Das, 1997; Erez \& Gati, 2004; Johnson, Lenartowickz \& Apud, 2006; Lenartowickz \& Roth, 1999; Nasif et al, 1991; Schaffer \& Riordan, 2003; Tayeb, 1994; Tsui, 2004). Lastly, there is the work of scholars who have re-initiated the epistemological arguments for the development of a science of culture (e.g. Boyacigiller \& Adler, 1994; Boyacigiller et al., 1996; Redding, 1994, 2003; Weisinger \& Salipante, 2000).

From this discussion, it appears that the problem of culture in international management scholarship has not been resolved. Even though many scholars have located themselves into the attainment phase, other international management scholars are still actively debating the problems of performing cultural research and are resurrecting epistemological arguments. It is at this point that this paper may make a contribution. Congruent with the work of Weisinger \& Salipante 2000, I argue that alternatives to the arguments about culture that so far have dominated international management can be found in areas of scholarly work that the field has been reluctant to acknowledge. Moreover, these alternative areas of research can provide answers to the questions posted by contemporary scholars that recognize the multilayered and ever changing nature of cultural phenomena which current cross-cultural management theory and method cannot explain (e.g. Leung et al., 2005). However, for these alternatives to make sense the field may need to understand its own ideas of "culture" in a very different way and develop new conceptualizations through a "post-attainment phase." This post-attainment phase would consider issues of culture for international management differently.

\section{Some Antecedents: The Crisis Of Representation In Cultural Anthropology}

Along with postmodern and postcolonial organizational theory, other developments in organizational studies have allowed for what I describe as a post-attainment phase to emerge. First is the importance of the work of Clifford Geertz, George Marcus, Michael Fisher and Renato Rosaldo in describing the crisis of representation in cultural anthropology. Second is the influence of scholars working within organizational culture.

The crisis of representation refers to a transitional moment in cultural anthropology when the canons for performing cultural research were keenly debated and new forms for doing cultural scholarship emerged. Many organizational scholars were deeply influenced by these debates (e.g. Martin \& Frost, 1996; Smircich, 1983; Stablein $\&$ Nord, 1985). However, their work, while greatly influential in organizational culture has not been as influential in 
international management scholarship (Boyacigiller \& Adler, 1994). The post-attainment phase I explain in the following sections builds on the work of these scholars.

\section{A POST-ATTAINMENT PHASE?}

In line with the genealogical approach that informs the paper, I forward this post-attainment phase as a heuristic device. This phase could be characterized as a period in international management scholarship that would incorporate cultural insights of contemporary social theory, such as postmodern and post-colonial theories and, in particular for the interest of this paper, Cultural Studies. I will not discuss contributions that postmodern and postcolonial theories may be able to make in international management scholarship since several other scholars have already done so (e.g., Banerjee \& Linstead, 2001; Calás \& Smircich, 1999; Kilduf \& Mehra, 1997; Prasad, 2003, Westwood, 2006). I will instead focus on Cultural Studies, for it is this theoretical approach that would speak more directly and forcefully to the problem of culture as an ontological problem.

The particular focus on Cultural Studies that I take in this paper emerged in the Centre for Contemporary Cultural Studies (CCCS) at the University of Birmingham and is informed by the work of Raymond Williams (1958, 1961, 1976 ) along with the contribution of contemporary Cultural Studies scholars (e.g. du Gay, 1996; du Gay et al. 1997; Rosaldo, 1993, 1997; Slack 1996), with particular emphasis on the work by Stuart Hall (1980a, 1980b, 1992, 1997a, 1997b). As such, the approach to Cultural Studies I take can be further identified as that of British Cultural Studies. Contemporary Cultural Studies scholars have expanded the original work of Raymond Williams (1958, 1961, 1976), Richard Hoggart (1957), and E.P. Thompson (1963) to include forms of social inquiry characteristic of the postmodern turn (Hall, 1980a, 1980b). I do not engage with the work of these scholars directly but present the implications of their work for the problem of culture in international management.

In general, a post-attainment phase informed by Cultural Studies would be characterized by the following:

- It would recognize the shifting meaning of the term culture through its use in describing social reality wherever it may happen. That is, our ideas about culture are always in the making, never stable, and always changing along with the social reality they attempt to describe. Consequently, it is impossible to stabilize and reify our understandings of culture either as a "process" or as a "parameter."

- It would place particular importance to analyzing the process of producing cultural knowledge. This entails understanding how the idea of culture is used, has been used in the past, and with what purposes by focusing on the particularities of cultural research and theory itself as a signifying practice.

- It would also require awareness of issues of power in the practice of cultural inquiry. This entails an awareness of the origins of our ideas about culture and the different uses and functions these ideas have served and continue to serve within the Western societies that originated them.

\section{Thinking "Culture"}

It is important to mention from the outset that, even though Cultural Studies might seem unrelated to international management, this is not the case: both fields of knowledge share a common origin in the debates about culture prevalent in the 1940s and 1950s. International management scholars, however, influenced by the structural functionalism of Talcott Parsons, provided different answers to these debates and, consequently, made different decisions than those taken by Raymond Williams and his followers. These common roots can be evidenced in the importance of Kroeber \& Kluckhohn's work (1952) for both fields (e.g. Boyacigiller et al. 1996; Williams, 1976).

Given the importance of Kroeber \& Kluckhohn's work as one of the historical roots for positivist international management research and also as one of the informants of Cultural Studies, it is important to take a closer look to this often ignored 'canonical' work. In their influential work, Culture: a critical review of concepts and definitions, Kroeber \& Kluckhohn (1952) made three important contributions to the study of culture: they 
historicized the shifting meanings associated with culture, created a summary of the definitions of culture provided by different fields of knowledge, and presented an argument for the empirical study of culture based on a clear culture parameter and sound scientific methods. However, management literature that quotes the work of Kroeber \& Kluckhohn typically cites it to prove the difficulty of defining culture or as a mere cataloging of definitions of culture. Nevertheless, the work of Kroeber \& Kluckhohn was much more than that. This work catalogued different definitions of culture, historicized the origins of the word culture, described the different meanings culture has had through history, explained the different practices of culture that originated from each new meaning, and described the particular social accomplishment culture in its contemporary semantic meaning represents for Western societies. Moreover, and perhaps more importantly, this work assisted in making the ontological argument that allowed structural functionalism to develop a science of culture (e.g. Kluckhohn \& Kroeber, 1961). The ontological resolution regarding culture achieved in this period was of great consequence for international management scholars by enabling the epistemological and methodological debates characteristic of the pre and attainment phases.

Thus, while international management scholars decided to follow the path to culture developed by Talcott Parsons, Clyde and Florence Kluckhohn, Fred Strodbeck, and Alfred Kroeber other scholars influenced by the work of Raymond Williams have used the same arguments exemplified by Kroeber and Kluckhohn and developed them into a different field of cultural inquiry. This other group of scholars advocated a field of "cultural" analysis that focused on the formation of the idea of culture itself as an on going process of meaning and social formation (e.g. Williams, 1982).

\section{Implications Of Cultural Studies As One Informant Within A Post-Attainment Phase}

Consequently, a post-attainment phase informed by Cultural Studies would develop a reflexive cultural inquiry, aware of its implication in creating specific meanings for culture through research, analysis and writing about culture (e.g. Rosaldo, 1993). This form of thinking and researching culture acknowledges the specific forms in which our ideas of culture emerge and are continuously changing through the practice and process of doing cultural inquiry. Moreover, this form of researching culture is aware of its own implication in circulating meaning within its own societies. That is, focuses on cultural research as a signifying practice.

This form of inquiry would explicitly acknowledge that in conducting cultural research, we are not just describing the process by which people create culture, neither are we just discovering structures or dimensions of culture that exist in the cultural system, but we are also continuously changing our very understanding of the concept ---i.e., we are creating and recreating the idea of culture. For the sheer reality of practicing cultural research, of conducting research and writing about culture unavoidably attaches new meanings to our notions of culture in a dynamic, continuous fashion. Therefore, "culture," the term we claim to be studying -- whether through a questionnaire or participant observation -- is never complete but always emergent alongside the reality under study.

Moreover, a post-attainment phase informed by Cultural Studies assumes that cultural inquiry is produced within systems of knowledge that have developed in the West; systems of knowledge that in turn have created very specific ways of representing those others, who traditionally have been the focus of cultural research and practice. Contemporary forms of cultural inquiry, independently of whether they are positivist or naturalistic, have developed within a Western historical context and it is these traditions for "exploring" culture the ones we use to conduct research and the ones we use when we write about cultural findings. This is a somewhat different argument from that of "cultural sensitivity" for it would acknowledge the semiotic importance of our descriptions about culture in circulating meaning within specific cultural systems. It would recognize not just that researchers come from a cultural specific context but also that their work is a cultural intervention that circulates meaning within their own cultural systems in very specific ways. The implication for international management is that the practice of writing and doing cultural research changes our meanings and practices about culture along with the social contexts in which the research is published and consumed. Consequently, a post-attainment phase informed by Cultural Studies will focus as well on how "meanings of culture" are already implicated in systems of power relations that emerged throughout the historical development of the concept and that continue to be present in contemporary uses of the idea of culture (e.g. Hall, 1996; Said, 1993). 
Furthermore, this form of thinking about culture recognizes that in the process of researching and writing about culture it is impossible for the researcher to separate from the systems of ideas and meanings existent in his/her own cultural system. That is, it is impossible for the researcher to detach herself (himself) from the historical processes that have created Western ideas about culture; we are the product of these histories and are also part of the new histories being written. Thus, we are always adjudicating meaning from within systems of signification present in our own cultural systems. This is not a new insight in international management research but it is new insofar as it is not considered as a limitation but rather as the only possible condition that would allow for cultural research to continue. Thus, the focus of "cross-cultural" research would change from making the subjects of research knowable to how they are translated through our own systems of ideas about culture.

Also, a post-attainment phase informed by Cultural Studies would not focus on whether culture exists or how we can obtain knowledge about it. Such a post-attainment phase would detach itself from traditional metaphysical arguments and would take an anti-essentialist stand on culture. It would consider "culture" not an essential human or social characteristic but as a term that is of human creation at a particular time and with a particular genealogy. That is, "culture" would be rendered not as the defining/essentialized human characteristic of both positivist and naturalist cross-cultural research, but as an idea embedded in a particular history, an idea that have had many different meanings and uses along its history and to which new meanings are still being assigned.

However, recognizing a genealogy of "culture" also implies recognizing the importance of its contemporary, albeit shifting, meanings as a set of practices that defines our notions of social organization. For instance, structural-functionalism as a way of framing the idea of culture for all societies was mostly a mirror of the principles of social organization prevalent in certain anglophone societies in the West at a particular point in time. Unfortunately, much of contemporary international management research continues to be a reflection of these principles. Cultural Studies would foster focusing on the origins of this form of thinking culture as a necessary step for transcending it.

Specifically, from a Cultural Studies perspective Western societies have developed a system of social organization around the Latin term cultüra, which has developed into a set of ideas and social practices over which a "cultural" order has emerged. Moreover, contemporary societies, whether Western or not, have adopted the idea of culture to describe their idiosyncrasies or to characterize their civilizations. Given this development of the idea of culture as an organizing principle for the West that has been transplanted to other societies around the globe Cultural Studies does not argue with culture but wants to call attention to the particular social and historical development contemporary ideas of culture represent (e.g.,Williams, 1976, 1982).

Further, our ideas of culture have had many meanings from their origin in Western Classic antiquity to contemporary times, and along with these shifting meanings the West has come to understand its own societies and those different from its own (e.g. Said, 1978; 1993). But this on-ongoing formation of the idea and practice of culture is in no way over. Thus, doing international management research in a post-attainment phase informed by Cultural Studies would recognize as normal the shifting meaning of the term culture along with the social reality being described through the term.

In summary, a post-attainment phase informed by Cultural Studies would take issue with how the idea of culture has been used in international management. The aim would be to move away from the problem of culture as it has been articulated in the quest for methods and attainment phases, with their focus on how "best" to understand culture and how "best" to obtain knowledge about it. International management scholarship would instead acknowledge that culture more than expressing an essential truth about different human groups is a metaconcept of social organization that is always in flux.

Therefore, if international management scholars aim to understand the ever-increasing complexity of "cultural" human differences around the planet it would be necessary to understand first the term used to translate and comprehend those differences. Attempts at defining, stabilizing, and reifying "culture" that have been typical in international management scholarship reduce rather than increase the ability to understand the concept and the social 
realities it purports to explain (e.g. Erez \& Gati, 2004). For instance, under conditions of globalization new cultural differences that do not correspond to national or geographic divides continue to emerge. Issues of massive migration, border cultures (such as those emerging in the US-Mexico border), and transportation and communication technologies have fostered the creation of new cultural forms that dominant constructs of culture cannot possibly explain or even acknowledge (e.g. Appadurai, 1990; Featherstone, 1995; Garcia-Canclini, 1989; Harvey, 1990; Manalansan \& Cruz-Malavé, 2002). To recognize these realities, then, Cultural Studies fosters understanding of the uses of the term culture, its development and its limits in order to present notions of culture that are malleable and that acknowledge the multiple realities of contemporary societies (e.g. Rosaldo, 1993; Slack, 1996). This requires uneasiness regarding theory and method, ambiguity as the only characteristic possible for cultural inquiry, and a commitment to change our methods and theories as "the new historical realities we engage keep also moving on down the road" (Slack, 1996: 114). Stuart Hall elaborates on this approach:

I want to suggest a different metaphor for theoretical work: the metaphor of struggle, of wrestling with angels. The only theory worth having is that which you have to fight off, not that which you speak with profound fluency (1992: 280).

\section{Repercussions For International Management: The Circuit Of Culture}

This discussion, however, still leaves open the question of how can we use this for research. If our ideas about culture are not stable but keep changing along with the reality under study, how then, can we possibly perform research? To answer this question scholars who worked at Centre but that later moved to the Open University developed the heuristic known as the Circuit of Culture (du Gay et al., 1997).

The Circuit of Culture is a heuristic that guides the researcher as she (he) attempts to understand connections among different social practices that might otherwise seem completely disconnected. This process is guided by the insights provided through articulation theory (Hall, 1980b, 1996b; Slack, 1996). The Circuit of Culture contextualizes the connections among different cultural practices: the cultural practices of the researcher and the practices of the people under study. However, for this article, I focus solely on the implications of the Circuit of Culture for researchers in cross-cultural management. This is accomplished by differentiating among several discrete moments in the process of cultural inquiry, these moments are: representation, production, consumption, identity, and regulation.

\section{REPRESENTATION}

The moment of representation focuses on how an idea is depicted symbolically and what meanings such depictions convey (e.g. Calás, 1987; Hall, 1997a ; Kilduff \& Mehra, 1997). For instance, when studying managerial practices in the maquiladoras of the US-Mexico border, a researcher will usually perform a literature review, which will encompass both the maquiladoras and the people working in them before conducting any empirical research. Furthermore, the researcher is exposed to other representations of maquiladoras and Mexico within her (his) cultural system, such as the popular and professional media, all of which convey differing and even contradictory representations of maquiladoras. Thus, at the moment of representation the researcher needs to focus on the specific meanings she (he) is decoding from within her (his) own cultural system and how these meanings are rendering her (his) object of study intelligible. 
Figure 1

The Circuit of Culture ${ }^{1}$

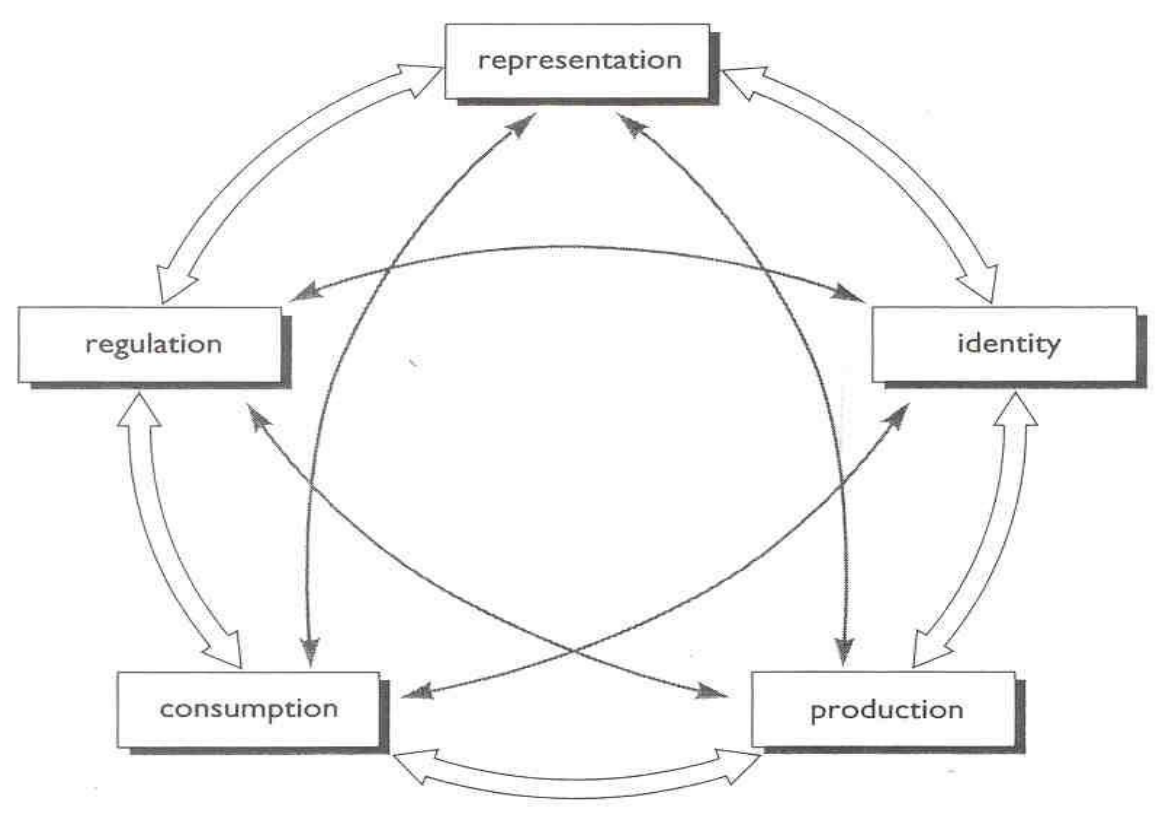

The circuit of culture

\section{PRODUCTION}

In the moment of production, analysis focuses on the processes that enable specific meanings about culture to be created and communicated within a social system (e.g. du Gay, 1997). Thus the analysis is on the material creation of a cultural product and how this product is encoded with certain meanings ${ }^{2}$.

The process of creating a cultural product demands that in order for that product to be intelligible it must be encoded with certain meanings; these meanings must be recognized as true by whoever is going to be the reader or consumer of the product. In the moment of production, chains of meaning existing in the linguistic system become attributed to a specific cultural product. Chains of meaning thus serve as a bridge between the producer of the cultural product and the consumers of it (Barthes, 1972). This process seems to be far from the realities of management and cross-cultural management. However, analysis of production for international management requires the analysis of the meanings produced in the process of creating a cultural product from within the multiple traditions of cultural inquiry present in the field. This is done by paying attention to the cultures of production and the work of cultural intermediaries. Cultural intermediaries are those people who work directly in assigning meaning to the idea of culture and who consequently are also responsible for circulating meaning about culture within their own societies

\footnotetext{
${ }^{1}$ Reproduced from: Hall, S. 1997. Representation: Cultural representations and signifying practices. London: Sage

${ }^{2}$ A cultural product is a generic term used to refer to anything that has a claim to culture, from an idea (like Culture) or a text (like a published OMJ article) among others.
} 
--- i.e. those who work within the culture industries (Bourdieu, 1984). On the other hand, the cultures of production refer to the specific rules and logics that determine the process of production.

Simply put, cultural intermediaries create a cultural product congruent with the specific set of norms, rules, and values considered important in specific cultures of production. As cultural intermediaries, international management scholars create a specific cultural product -research- according to specific traditions of discourse (positivist, naturalistic, etc.). Thus, if the rules and values of specific traditions of discourse have been followed and recognized as "true" by the consumers of the cultural product, then, in the moment of "discussion" or "implications;" what can kinds of meanings can be created and circulated into the cultural system? What are the limits to the meanings that can be created?

\section{CONSUMPTION}

Consumption focuses on the users of the cultural product --- i.e. consumers --- and the actions they perform based on their decoding of the cultural product (Mackay, 1997). That is, users of discourse must extract meaning and acknowledge it as "valid." Specific actions are legitimated and enacted based on this consumption. For instance, before an international management researcher performs research, this person performs a literature review and consumes specific representations that inform her (him) about his subject of study and how to obtain knowledge about it. These representations convey meaning and prescribe specific actions that must be followed if "true" knowledge is to be obtained within specific cultures of production. Consequently, the moment of consumption allows the researcher to recognize how she (he) is encountering her (his) object of study and how she (he) is making it knowable, through the gaze of the specific forms for "doing" culture she (he) has been exposed to. These forms of "doing" culture also influence the arguments and meanings about culture that can be made and circulated within the social system of the researcher.

\section{IDENTITY}

The moment of identity analyzes how we develop a sense of self through consumption (e.g. Townley, 1993; Woodward, 1997). In the moment of consumption, the researcher also becomes a subject of the text to which he is being exposed to (Martin, Gutman \& Hutton, 1988). In other words, the process of consumption speaks back to the researcher about some truth, which is an essential component of the sense-making process of the researcher. This relationship means that the researcher is personally involved, that the process of consumption speaks back to her (him) about some truth and that maintaining that truth is an important part of the sense-making process for the researcher.

But researchers become subjects of the multiple representations they consume from within their social systems. Some of these representations researchers acknowledge but other representations and the meanings they convey are not acknowledged, even though they still form part of a researcher's sense of self. This is the difference that Barthes (1972) identified as languages and metalanguages. Researchers must acknowledge how the multiple cultures of which they are part --- besides the academic---- inform who they are, and how such identity informs the "significance" of their research findings.

\section{REGULATION}

The moment of regulation in the Circuit of Culture focuses on different aspects depending on the specific context (Thompson, 1997). In general, regulation allows understanding different practices of control within the cultural system (e.g. Wong-MingJi \& Mir, 1997). That is, the moment of regulation hones in on the issues of power that create limits for systems of meaning; it also investigates classificatory systems of culture that include and exclude certain practices of culture and, consequently, certain meanings about culture. This focus on power can take many forms; for instance, obedience of cultures of production or systems for knowledge creation can control what kind of meanings can be made or justify specific meanings advocated by specific groups. This is similar but not quite as the now famous power-knowledge argument in critical management studies (e.g. Townley, 1993). Another 
example is the politics of research, including the personal elements of research that usually are not acknowledged but that nevertheless form part of the research process. For example, if I am one of the principal researchers engaging in a huge multinational project to compare hundreds of societies, how is my institutional and social location as "main researcher" affecting the voices of the people under study as well as the kinds of arguments and meanings that can be forged? If, for instance, an associate researcher protests my research policies and protocols, is this protest based on the lack of scientific knowledge or is it aimed at wider processes of meaning creation about her (his) own culture? This is the kind of analysis that the moment of regulation requires: the recognition of power dynamics in the process of cross-cultural inquiry (Wolf, 1990).

In general, regardless of the methodological approach taken (qualitative or quantitative) the Circuit of Culture allows for spaces of arbitrary fixation in the process of research that allow the researcher to focus on her (his) own cultural location and how this location affects the research process.

\section{CONCLUSION}

This interpretation of the literature describes ways in which international management scholars have dealt with the idea of culture for over four decades. I have organized this literature in terms of the decisions that scholars have implicitly made about the status of the idea of culture. These decisions have moved scholars within the field to address the problem of culture mostly as an epistemological or a methodological issue while neglecting ontological concerns. What distinguishes the quest for methods from the attainment phase is a stand regarding a general theory that could provide a clear parameter of culture - scholars in the quest for methods phase did not have it and were actively searching for it - and scholars in the attainment phase, at least those positioned in the mainstream of the field, assume that they have it and therefore have focused their efforts on issues of methodology. As the international management field moved through the quest for methods and attainment phases, the emphasis on these issues fluctuated according to the degree to which scholars within the field have attempted to find out what is the field's raison d'être (e.g., Toyne \& Nigh, 1998). During the quest for methods phase, scholars focused on developing a science of culture that could allow the comparison of managerial practices among different nations.

On the other hand, during the attainment phase epistemological arguments have taken a secondary place. Informed by a functionalist epistemology there has been an explosion of research centered on certain constructs of culture. However, scholars are still voicing their discontent with the field's positioning into a premature normal science phase and are re-initiating a debate which may finally address the ontological status of the idea of culture in international management scholarship (e.g. Redding, 1994).

In general, the lack of historical analysis about international management's origins along with the lack of ontological analysis of its own ideas about culture can be blamed for many of the field's problems and on going debates. For example, the field's essentialist assumptions about "culture," its adoption of structuralist functionalist approaches and, consistent with these approaches, the default adoption of the realist ontological stand of cultural anthropologists influenced by Talcott Parsons (e.g. Kluckhohn \& Strodbeck, 1961; Kroeber \& Kluckhohn, 1952). In many ways, the field remains ontologically fixated on the idea of culture from the era of structural-functionalism in cultural anthropology (e.g. Hofstede, 1980; House et al., 2004; Schwartz, 1994). In the meantime many cultural anthropologists like Clifford Geertz (1983) or Renato Rosaldo (1993) have offered multiple critiques of their own field's ideas of culture and presented alternatives for research. In fact, cultural anthropology abandoned structural functionalism a long time ago and, through a very strong reflective turn, has even problematized phenomenological approaches for the study of culture and its own ethnographic tradition (e.g. Adam \& Allan, 1995; Clifford \& Marcus, 1986; Geertz, 1983; Harris, 1999; Marcus \& Fisher. 1986; Rosaldo, 1993; Surber, 1998).

International management scholarship, on the contrary, has avoided addressing issues of culture from an ontological standpoint despite the influx of ontological debates in organizational theory since the late 1970s (e.g. Burrell \& Morgan, 1979), including more recent postmodernist and poststructuralist arguments (e.g., for a review, Calás \& Smircich, 1999). The field has avoided reflecting on its assumptions about the existence of culture and how these ideas of culture are produced; it therefore has constantly returned to the same set of epistemological and 
methodological problems without finding a way out. However, as proposed in this paper, only by analyzing the idea of culture as always problematic can new forms of understanding culture in fact emerge.

A post-attainment phase informed by Cultural Studies (along with postmodern and postcolonial organizational theory) can help in this ontological quest. Specifically, a post-attainment phase would focus on the particularities of cultural research that differentiate this form of inquiry from other forms of organizational and sociological research (Hall, 1997b; Williams, 1982). If we international management scholars are going to move away from the problem of culture as it has traditionally been conceptualized we must recognize the ever changing nature of our ideas about culture. Thus, we must face the impossibility of stabilizing the concept since it changes along with the reality it contends to describe. I am not suggesting, as some might think, that given these difficulties we should avoid using culture for research; if we attempt to do this, we will also try to ignore one of the most important systems of ideas developed by Western civilizations. Instead, we need to accept this ever changing characteristic as the only condition for research to continue.

From a Cultural Studies perspective, only by engaging with the problematic origin of the idea of culture and the way it has been used and produced in international management scholarship may it be possible to develop a critical analysis of our practices of cultural inquiry. This kind of analysis would allow for new forms of cultural research to be found and for new notions of culture to emerge by developing a critical understanding of the epistemological traditions from which our own system of cultural knowledge have emerged (e.g. Wolf, 1990). Said differently, we must analyze the origins and uses of the international management discourses about culture within the societies that originated and continue to originate them.

I also presented alternatives for cultural inquiry from the "field" of Cultural Studies. This alternative draws attention to our shifting and often contradictory notions about culture, underscoring how they inform our research (Martin \& Frost, 1996; Martin, 2002). If, as Hall (1997b) points out, all social practices "express or communicate meaning," our cultural inquiry also constitutes a signifying practice that may reproduce or challenge the different senses of the notion of culture.

Instead of just concluding that cultural inquiry is condemned to bias, the Circuit of Culture suggests that acknowledging the fact that cultural inquiry is a form of cultural production implies changes in our way of conducting cross-cultural research. Such self-awareness goes one step further than the dominant forms of research in international management. Traditionally, forms of self-criticism within international management aim to avoid charges of parochialism -the neglect of non-Western cultural contexts in the development of cross-cultural theory and method- by including different voices in the process of research and theorizing (e.g. Boyacigiller \& Adler, 1991). While valuable, this position obscures the fact that the cultural biases are already embedded in the methods (regardless of whether they are quantitative or qualitative), in the cultures of production that rule the actions of the cultural intermediaries and that shape the process of cultural production. On the other hand, the Circuit of Culture underscores how our traditions and systems of signification determine our scholarship and therefore the arguments and meanings that we international management scholars communicate to the multiple constituencies to which we belong. As Calás \& Smircich (1999) explain, "at the very moment the complicity of language in the constitution of knowledge becomes part of the 'conversation,' the 'tone" of the conversation has to change." This is true, however, but only if we care to understand the consequences of our traditions and systems of signification in determining the meanings international management scholars can create and the practices that are informed by these meanings.

\section{AUTHOR INFORMATION}

Carlos B. González is an organizational behavior scholar and consultant in both his native Puerto Rico and the U.S. Currently, Dr. González is faculty at California State Polytechnic University, Pomona. He earned his doctorate in Management from the University of Massachusetts at Amherst. His research interests include diversity and crosscultural management. 


\section{REFERENCES}

1. Adam, B., \& Allan, S. 1995. Theorizing culture, New York: New York University Press.

2. Adler, N.J. 1983a. A typology of management studies involving culture. Journal of International Business Studies. Fall, pp. 29-47.

3. Adler, N.J. 1983b. Cross-cultural management: issues to be faced. International Studies of Man \& Organization. Vol. XIII, no. 1-2, pp. 1-45.

4. Adler, N.J. 1983c. Cross-cultural management research: the ostrich and the trend. Academy of Management Review, 8: 226-232.

5. Adler, N.J. 1984. Understanding ways of understanding: cross-cultural management methodology reviewed. In R.N. Farmer (Ed.), Advances in international comparative management, Greenwich, CT: JAI Press

6. Adler, N.J,, \& Villafranca, J. 1981. Bibilography : selected books and articles.

7. Adler, N. J., \& Villafranca, J. d. 1981. Bibliography: selected books and articles by participants in the McGill International Symposium on Cross-Cultural Management. Montreal: McGill University.

8. Aldemir, M.C. 1986 The impact of cultural values upon manager's choice of social power base. International Journal of Manpower, 7(5): 13-19.

9. Almeida, P., Grant, R., \& Anupama P. 2002. Knowledge acquisition through alliances: Opportunities and challenges. In M.J, Gannon and K.L. Newman (eds.), The blackwell handbook of cross-cultural management. Malden, MA: Blackwell Business.

10. Appadurai, A. 1990. Disjuncture and difference in the global culture economy, Theory, Culture, and Society, 7: 295-310.

11. Aycan, Z. 2000. Cross-cultural industrial and organizational psychology. Journal of Cross-Cultural Psychology, 31(1): 110-128.

12. Barthes, R. 1972. Mythologies. New York: Hill \& Wang.

13. Barret, G.V., \& Bass, B.M. 1976. Cross-cultural issues in industrial and organizational psychology. In M.D. Dunnette (Editor), Handbook of industrial organizational psychology, Chicago: Rand McNally College Publishing Company.

14. Banerjee, S.B. and Linstead, S. 2001. Globalization, multiculturalism and other fictions: Colonialism for the new millenium? Organization, 8: 683-722.

15. Bhagat, R.S., \& McQuaid S.J. 1982. Role of subjective culture in organizations: A review and direction for future research. Journal of Applied Psychology Monograph. 67(5): 653-685.

16. Boyacigiller, N.A., and Adler, N.J. 1991. The parochial dinosaur: Organizational science in a global context. Academy of Management Review, 16(2): 262-290.

17. Boyacigiller, N.A., \& Adler, N.J. 1994. Insiders and outsiders: bridging the worlds of organizational behavior and international management. In B. Toyne and D. Nigh (Eds.), International business inquiry: An emerging vision, Columbia, SC: University of South Carolina Press.

18. Boyacigiller, N.A., Kleinberg, M.J., Phillips, M.E., \& Sackman, S.A. 1996. Conceptualizing culture. In B.J. Punnett and O.S. Shenkar (Eds.), Handbook for international management research. Pp. 157-208.

Cambridge, MA: Blackwell.

19. Bourdieu, P. 1984. Distinction: A social critique of the judgement of taste, Cambridge, MA: Harvard University Press.

20. Burrell, G., \& Morgan, G. 1979. Sociological paradigms and organizational analysis. London: Heineman Educational Books.

21. Burrell, G. 1996. Normal science, paradigms, metaphors, discourses and genealogies of analysis. In S.R. Clegg, C. Hardy, and W.R. Nord (Eds.), Handbook of organization studies. London: Sage Publications.

22. Calás, M.B. 1987. Organizational science fiction: The postmodern in the management disciplines. Unpublished doctoral dissertation. University of Massachusetts, Amherst.

23. Calás, M.B., \& Smircich, L. 1999. Past postmodernism? Reflections and tentative directions, Academy of Management Review, 24(4): 649-671.

24. Cavusgil, S.T., \& Das, A. 1997. Methodological issues in empirical cross-cultural research: A survey of the management literature and a framework. Management International Review. 37(1): 71-96. 
25. Child, J. \& Tayeb, M. 1982. Theoretical perspective in cross-national organizational research. International Studies of Management and Organization, Winter.

26. Clifford, J., \& Marcus, G.E. 1986. Writing culture: The poetics and politics of ethnography, Berkeley and Los Angeles: University of California Press.

27. Daft, R., \& Lewin, A.Y. 1990. Can organization studies begin to breakout of the normal science straightjacket? Organization Science, 1(1):1-9.

28. Drenth, P. 1985. Cross-cultural organizational psychology: challenges and limitations. In P. Joynt and M. Warner (Eds.), Managing in different organizations, Amsterdam: Universitetsforlaget.

29. du Gay, P. 1997. Production of Culture/Cultures of Production. London: Sage.

30. du Gay, P., Hall, S., Janes, L., Mackay, H., \& Negus, K. 1997. Doing cultural studies: The story of the Sony Walkman. London: Sage.

31. Earley, P.C., \& Singh, H. 2000. Innovations in international and cross-cultural management. Thousand Oaks: Sage.

32. England, G.W. 1978. Managers and their value systems: a five country comparative study, Columbia Journal of Comparative Studies, 13(2): 35-44.

33. Erez, M. \& Earley, P.C. 1993. Culture, identity, and work .New York: Oxford University Press.

34. Erez, M. \& Gati, E. 2004. A dynamic, multilevel model of culture: from the micro level of the individual to the macro level of a global culture, Applied Psychology: An international Review, 53(4): 583-598.

35. Evan, W. 1973. Measuring the impact of culture on organizations. International studies of Management and Organizations, 5 (1):91-113.

36. Farmer, R.N., \& Richman, B.M. 1965. Comparative management and economic progress. New York: John Willey.

37. Featherstone, M. 1995. Undoing culture: globalization, postmodernism and identity. London: Sage.

38. Feldman, S.P. 1986. Management in context: an essay on the relevance of culture to the understanding of organizational change. Journal of Management Studies, 23(6): 587-607.

39. Fisher, R., Redford, P., Ferreira, M.C., Harb, C. \& Leal Assmar, E.M. 2005. Organizational Behaviour across Cultures: Theoretical and methodological issues for developing multilevel frameworks involving culture. International Journal of Cross Cultural Management, 5(1): 27-48.

40. Foucault. M. 1972. The archeology of knowledge and the discourse on language. New York: Pantheon Books.

41. Garcia-Canclini, N. 1989. Hybrid cultures: strategies for entering and leaving modernity. Minneapolis: University of Minnesota Press.

42. Geertz, C. 1973. The interpretation of cultures. New York: Basic Books.

43. Gelfand, M.J., Erez, M., \& Aycan, Z. 2007. Cross-cultural organizational behavior, Annual Review of Psychology, 58:479-514.

44. Haire, M., Ghiselli, E.E., \& Porter, L. 1966. Managerial thinking: An international study. New York: Wiley.

45. Hall, E.T. 1959. The silent language. New York: Doubleday.

46. Hall, S. 1980a. Cultural Studies at the Centre: Some problematics and problems. In Culture, media, language. Pp. 15-47. London: Hutchinson.

47. Hall, S. 1980b. Encoding/decoding. In Culture, media, language. Pp. 128-138, London: Hutchinson.

48. Hall, S. 1992. Cultural Studies and its theoretical legacies. In L. Grossberg, C. Nelson and P. Treichler (Eds.), Cultural studies. New York: Routledge.

49. Hall, S. 1996. The West and the rest: discourses and power. In S. Hall, D. Held, D.Hubert, and K. Thompson (Eds.), Modernity: An introduction to modern societies. Cambridge, Mass.: Blackwell.

50. Hall, S. 1997a. The work of representation. In S. Hall (Ed.), Representation: Cultural representations and signifying practices. London: Sage.

51. Hall, S. 1997b. The centrality of culture: Notes on the cultural revolutions of our time. In K. Thompson (Ed.), Media and cultural regulation. London: Sage.

52. Hall, E.T., \& Hall, MR. 1990. Understanding cultural differences. Yarmouth, ME: Intercultural Press.

53. Harbison, F., \& Myers, C.A. 1959. Management in the industrial world: An international analysis. New York: McGraw. 
54. Harris, M. 1999. Theories of culture in postmodern times, Walnut Creek: Altamira.

55. Harvey, D. 1990. The condition of postmodernity. Cambridge: Blackwell.

56. Hofstede, G. 1976. Nationality and espoused values of managers. Journal of Applied Psychology, 61: 14855.

57. Hofstede, G. 1980. Culture's consequences: International differences in work related values. Newbury Park: Sage Publications.

58. Hofstede, G. 1991. Cultures and organizations: Software of the mind. London: McGraw-Hill.

59. Hofstede, G. 2006. What did GLOBE really measure? Researchers' minds versus respondents' minds, Journal of International Business Studies, 37 (6): 882-896.

60. Hoggart, R. 1957. The uses of literacy. New Brunswick \& London: Transaction Publishers.

61. House, R.J., Hanges, P.J., Javidan, M., Dorfman, P.W. \& Gupta, V. (Eds.) 2004. Culture, leadership, and organizations: The GLOBE study of 62 societies. Thousand Oaks: Sage.

62. Inzerilli, G. 1981. Preface: some conceptual issues in the study of the relationships between organizations and societies. International Studies of Management and Organization, 10(4): 3-14.

63. Jamieson, I.M. 1982. The concept of culture and its relevance for an analysis of business enterprise in different societies. International Studies of Business and Organization. 12 (4): 71-105.

64. Johnson, J.P., Lenartowicz, T. \& Apud, S. 2006. Cross-cultural competence in international business: toward a definition and a model. Journal of International Business Studies, 37: 525-543.

65. Kirkman, B.L., Lowe, K.B., \& Gibson, C. (2006) A quarter century of Culture's Consequences: A review of empirical research incorporating Hofstede's cultural values framework. Journal of International Business Studies, 37: 285-320.

66. Kilduff,M., \& Mehra, A. 1997. Postmodernism and organizational research. Academy of Management Review, 22: 453-481.

67. Kluckhohn, C. 1951. Values and value orientation in the theory of action: an exploration in definition and classification. Toward a General Theory of Action, Cambridge, MA: Harvard University Press.

68. Kluckhohn, C. 1962. Universal categories of culture. In S. Tax (Ed.) Anthropology today. Chicago: University of Chicago Press.

69. Kluckhohn, F.R., \& Strodbeck. F.L. 1961. Variations in value orientations. Evanston, IL: Peterson.

70. Kroeber, A.L., \& Kluckhohn, C. 1952. Culture: a critical review of concepts and definitions. Papers of the Peabody Museum of American Archeology and Ethnology. Harvard University, Vol. XLVII-No.1.

71. Kroeber, A.L., \& Parsons, T. 1958. The concepts of culture and of social system. American Sociological Review. Vol. 23.

72. Lammers, C.J., \& Hickson D.J. 1979. Organizations alike and unlike: International and inter-institutional studies in the sociology of organizations. Boston: Routledge.

73. Lenartowicz, T., \& Roth, K. 1999. A framework for culture assessment. Journal of International Business Studies. 30(4): 780-798.

74. Leung, K., Bhagat, R.S., Buchanan, N.R., Erez, M., \& Gibson, C.B. 2005. Culture and international business: recent advances and implications for future research. Journal of International Business Studies, 36: 357-378.

75. Lim, L.L., \& Firkola, P. 2000. Methodological issues in cross-cultural management research: Problems, solutions, and proposals. Asia Pacific Journal. 17: 133-154.

76. Lincoln, J.R., Hanada, M., \& Olson, J. 1981. Cultural effects on organizational structure: the case of Japanese firms in the United States. American Sociological Review, 43:829-47.

77. Mackay, H. 1997. Consumption and everyday life. London: Sage.

78. Manalansan, M. \& Cruz-Malavé, A. 2002. Queer globalizations: Citizenship and the afterlife of colonialism, New York: New York University Press.

79. Marcus, G.E. \& Fischer, M.J. 1986. Anthropology as cultural critique: An experimental moment in the human sciences. Chicago and London: The University of Chicago Press.

80. Marsden, R., \& Townley, B. 1996 The owl of Minerva: Reflections on theory in practice. In S.R. Clegg, C. Hardy, and W.R. Nord (Eds.), Handbook of organization studies. London: Sage Publications.

81. Martin, L.H., Gutman, H., \& Hutton, P.H. 1988. Technologies of the self: A seminar with Michel Foucault. University of Massachusetts Press. 
82. Martin, J., \& Frost, P. 1996. The organizational culture war games: a struggle for intellectual dominace. In S.R. Clegg, C. Hardy, and W.R. Nord (Eds.), Handbook of organization studies. London: Sage Publications.

83. McSweeney, B. 2002. Hofstede's model of national cultural differences and their consequences: A triumph of faith, a failure of analysis. Human Relations. 55(1): 89-118.

84. Meyer, K. (2007) Contextualizing organizational learning: Lyles and Salk in the context of their research. Journal of International Business Studies, 38: 27-37.

85. Mir, R.A., Calás, M.B. and Smircich, L. 1999. Global technoscapes and silent voices: Challenges to theorizing global cooperation. In D. L. Cooperrider and J.E. Dutton (Eds.) Organizational dimensions of global change: No limits to cooperation, p. 270-290. Newbury Park: Sage.

86. Morris, M.W., Podolny, J.M., \& Ariel, S. 2000. Missing relations: incorporating relational constructs into models of culture. In P.C. Earley and H. Singh (Eds.), Innovations in international and cross-cultural management, Thousand Oaks: Sage Publications.

87. Nasif, E.G., Al-Daeaj,H., Ebrahimi, B. \& Thibodeaux, M.S. 1991. Methodological problems in crosscultural research: An updated review. Management International Review, 31:79-91.

88. Nath, R. 1986. Role of culture in cross-cultural and organizational research. Advances in International Comparative Management, Vol. 2, pp. 249-267.

89. Parsons, T. 1964. Social structure and personality. New York: Free Press.

90. Parsons, T. 1977. The evolution of societies. New Jersey: Prentice Hall.

91. Parsons, T., \& Shils, E.A. 1951. Toward a general theory of action. Cambridge, MA: Harvard University Press.

92. Punnett, B.J., \& Shenkar, O. 1996. Handbook of international management. Cambridge, MA: Blackwell.

93. Prasad, A. 2003. Postcolonial theory and organizational analysis: a critical engagement. New York : Palgrave Macmillan

94. Redding, G.S. 1994. Comparative management theory: Jungle, zoo or fossil bed. Organization Studies. 15(3): 323-359.

95. Rhinesmith, S. 1970. Cultural organizational analysis: The interrelationship of value orientation and managerial behavior. Cambridge,MA: McBer Publication Series.

96. Roberts, K.H. 1970. On looking at an elephant: An evaluation of cross-cultural research related to organizations. Psychological Bulletin. 74(5): 327-350.

97. Roberts, K.H., \& Boyacigiller, N.A. 1984 Cross national organizational research: the grasp of the blind men. Research in Organizational Behavior, Vol. 6. JAI Press: Greenwich, CT.

98. Ronen, S., and Shenkar, O. 1985. Clustering countries on attitudinal dimensions: A review and synthesis. Academy of Management Review. 10(3): 435-454.

99. Rosaldo, R. 1993. Culture and truth: The remaking of social analysis. London: Routledge.

100. Rosaldo, R. 1997. Whose cultural studies? Cultural studies and the disciplines. In P. Gibian (Ed.), Mass culture and everyday life. New York: Routledge.

101. Said, E. 1978. Orientalism. Pp. 1-28. New York: Vintage Books.

102. Said, E. 1993. Culture and imperialism. New York: Knopf.

103. Schaffer, B.S. \& Riordan, C.M. 2003. A review of cross-cultural methodologies for organizational research: A best- practices approach. Psychology \& Developing Societies, 15 (1): 1-29.

104. Schwartz, S.H. 1992. Universals in the content and structure of values: Theoretical advances and empirical tests in 20 countries. In M.P. Zanna (Ed.) Advances in Experimental Social Psychology, 25:1-65, New York: Academic Press.

105. Schwartz, S.H. 1994. Beyond individualism/collectivism: new cultural dimensions of values. In U. Kim, H.C Triandis, C. Kagitsibasi, S. Choi, G. Yoon (eds.), Individualism \& collectivism: Theory, method and application. Thousand Oaks: Sage.

106. Schein, E.H. 1985. Organizational culture and leadership. San Francisco: Jossey-Bass.

107. Sekaran, U. 1983 Methodological and theoretical issues and advancements in cross-cultural research. Journal of International Business Studies. 14(2): 61-73.

108. Shenkar, O. 2001. Cultural distance revisited: towards a more rigorous conceptualization and measurement of cultural differences. Journal of International Business Studies. 32(3): 519-535. 
109. Shenkar, O., \& Zeira, Y. 1992. Role conflict and role ambiguity of chief executive officers in international joint ventures. Journal of International Business Studies, 23(1):55-75.

110. Singh, K. 2007. The limited relevance of culture to strategy, Asia Pacific Journal of Management, 24(4): 421-429.

111. Slack, J. 1996. The theory and method of articulation in cultural studies. In D. Morley and K.H. Chen (Eds.), Stuart Hall: Critical dialogues in cultural studies. Pp. 112-127, London: Routledge.

112. Smith, P.B. Meeting the challenge of culture difference. 2003. In D. Tjosvold and K. Leung (eds.), Crosscultural management: Foundations and future. Hampshire, UK: Ashgate.

113. Sorge, A. 1982. Cultured organization. International Studies of Management and Organization, Winter, pp. 106-138.

114. Søndergaard, M. 1994. Research note: Hofstede’s consequences: A study of reviews, citations and replications. Organization Studies. 15(3): 447-456.

115. Sullivan, J. 1994. Theory development in international business research: the decline of culture. In B. Toyne and D. Nigh (Eds.), International business inquiry: An emerging view. Columbia, SC: University of South Carolina Press.

116. Surber J.P. 1998. Culture and critique: An introduction of the critical discourses of cultural studies, Boulder, Colorado: Westeview Press.

117. Tagiuri, R. 1965. Value orientations and the relationships of managers and scientists. Administrative Science Quarterly, June: 39-51.

118. Tanaka, Y., \& Osgood, C.E. 1962. Cross-cultural, cross-concept and cross-subject generality of affective meaning systems. Journal of Personality and Social Psychology, 2, 143-153.

119. Tayeb, M. 1994. Organizations and national culture: methodology considered. Organization Studies. 15(3): 429-446.

120. Tjosvold, D., \& Leung, K. 2003. Cross-cultural management: Foundations and future. Hampshire, UK: Ashgate.

121. Thompson, E.P. 1963. The making of the English working class. London: Penguin.

122. Thompson, K. 1997. Regulation, de-regulation and re-regulation. In K. Thompson (Ed.), Media and cultural regulation. London: Sage.

123. Townley, B. 1993. Foucault, power/knowledge, and its relevance for human resource management. Academy of Management Review, 18: 518-545.

124. Toyne, B., \& Nigh, D. 1998. A more expansive view of international business. Journal of International Business Studies. 29 (4): 863-876.

125. Triandis, H.C. 1972 The analysis of subjective culture, New York: Wiley.

126. Triandis, H.C. 1982. Dimensions of cultural variation as parameters of organizational theories. International Studies of Management and Organizations, 12: 139-169.

127. Triandis, H.C. 1983. Some dimensions if intercultural variation and their implications for community psychology. Journal of Community Psychology, 11: 285-302.

128. Triandis, H.C. 2003. Forty five years of researching the culture and behavior link: An intellectual autobiography. In D. Tjosvold and K. Leung (eds.), Cross-cultural management: Foundations and future. Hampshire, UK: Ashgate.

129. Trompenars, F. 1993. Riding on the waves of culture. London: Nicholas Brealey.

130. Tsui, A.S. 2004. Contributing to global management knowledge: A case for high quality indigenous research, Asia Pacific Journal of Management, 21(4): 491-513.

131. Tsui, A.S., Nifadkar, S.S., \& Yi Ou, A. 2007. Cross national, cross-cultural organizational behavior research: Advances, Gaps, and Recommendations, Journal of Management, 33(3): 426-478.

132. Van Maanen, J., \& Laurent, A. 1991. The flow of culture: some notes on globalization and the multinational corporation. In S. Goshal and D.E, Westney (Eds.), Organizational theory and the multinational corporation. New York: St. Martins Press.

133. Weisinger, J.Y., \& Salipante, P.F. 2000. Cultural knowing as practicing: extending our conceptions of culture. Journal of Management Inquiry, 9(4): 376-390.

134. Weiss, R.M. 1983. Weber on bureaucracy: management consultant or political theorist? Academy of Management Review. 8(2): 242-248. 
135. Werner, S. 2002. Recent developments in international management research: A review of 20 top management journals, Journal of Management, 28(3): 277-305.

136. Westwood, R. (2006) International business and management studies as an orientalist discourse: A postcolonial critique. Critical Perspectives on International Business, 2(2): 91-113.

137. Williams, R. 1958. Culture and society: 1780-1950. London: Penguin.

138. Williams, R. 1961. The long revolution, pp. 41-71. New York: Columbia University Press.

139. Williams, R. 1976. Keywords. New York: Oxford University Pres.

140. Williams, R. 1982. The sociology of culture. New York: Schocken Books .

141. Wright, R.W. \& Ricks, D.A. 1994. Trends in international business research: twenty five years later. Journal of International Business Studies, Fourth Quarter.

142. Woodward, K. 1997. Concepts of identity and difference. In K. Woodward (Ed.), Identity and difference, London: Sage.

143. Wolf, E.R. 1990. Facing power: old insights, new questions. American Anthropologist. 92(3):586-596.

144. Wong-MingJi, D. J., \& Mir, A. H. 1997. How international is international management? Provincialism, parochialism, and the problematic of global diversity. In Prasad, P., Mills, A. J., Elmes, M., \& Prasad, A. (eds) Managing the Organizational Melting Pot: Dilemmas of Workplace Diversity. Beverly Hills, CA: Sage Publications. 340-364

\section{NOTES}

